IZA DP No. 10228

Increasing Rural Health Clinic Utilization with SMS Updates: Evidence from a Randomized Evaluation in Uganda

Luke E. Chicoine

Juan Carlos Guzman

September 2016 


\title{
Increasing Rural Health Clinic Utilization with SMS Updates: Evidence from a Randomized Evaluation in Uganda
}

\author{
Luke E. Chicoine \\ DePaul University \\ and IZA \\ Juan Carlos Guzman \\ University of Notre Dame
}

Discussion Paper No. 10228

September 2016

IZA

P.O. Box 7240

53072 Bonn

Germany

Phone: +49-228-3894-0

Fax: +49-228-3894-180

E-mail: iza@iza.org

Any opinions expressed here are those of the author(s) and not those of IZA. Research published in this series may include views on policy, but the institute itself takes no institutional policy positions. The IZA research network is committed to the IZA Guiding Principles of Research Integrity.

The Institute for the Study of Labor (IZA) in Bonn is a local and virtual international research center and a place of communication between science, politics and business. IZA is an independent nonprofit organization supported by Deutsche Post Foundation. The center is associated with the University of Bonn and offers a stimulating research environment through its international network, workshops and conferences, data service, project support, research visits and doctoral program. IZA engages in (i) original and internationally competitive research in all fields of labor economics, (ii) development of policy concepts, and (iii) dissemination of research results and concepts to the interested public.

IZA Discussion Papers often represent preliminary work and are circulated to encourage discussion. Citation of such a paper should account for its provisional character. A revised version may be available directly from the author. 
IZA Discussion Paper No. 10228

September 2016

\section{ABSTRACT}

\section{Increasing Rural Health Clinic Utilization with SMS Updates: Evidence from a Randomized Evaluation in Uganda*}

This paper examines an alternative to monitoring staff at a public health clinic in rural Uganda. The program sent SMS updates regarding confirmed attendance of clinic staff and activities to randomly selected cell phone-owning households in the local community. A difference-in-difference approach is used to evaluate the impact of the SMS program, and finds the messages led to an increase in clinic attendance, the receipt of medicine, and reduced duration of illness for young children aged six and under. However, these benefits are only seen for children who are the same sex as the cell phone owner, suggesting favoritism towards the health of these children. These benefits are found to be similar for both boys and girls.

JEL Classification: $\quad$ I15, J13, O22

Keywords: mobile technology, parental favoritism, children's healthcare, Uganda

Corresponding author:

Luke Chicoine

Department of Economics

DePaul University

1 East Jackson Blvd, Suite 6200

Chicago, IL 60604

USA

E-mail: Ichicoin@depaul.edu

\footnotetext{
* We would like to thank the generous participation of the people of Nnindye Parish; as well as the staff from the Health Clinic and the Uganda Martyrs University (UMU) for permission and assistance to undertake this research. The dedicated work of field assistance, including Apolo Kasharu and Juliet Nambuubi at UMU, and Sarah Dawson and Tom Marentette, who coordinated the data collection in the clinic and the technology to send text messages, from the University of Notre Dame. Data in this paper were collected thanks to Fr. Robert Dowd and Dennis Haraszko in The Ford Family Program in Human Development Studies and Solidarity at the University of Notre Dame, and a grant from the Verizon Foundation.
} 


\section{Introduction}

Inconsistent attendance of public employees in schools and local health clinics is a well-documented problem in many parts of the developing world (Chaudhury et al., 2006). High levels of absenteeism significantly reduce the potential benefit of seeking medical care, and reduce the likelihood of take-up even when the potential patients choose to journey to the clinic (Goldstein et al., 2013). External monitoring has proven difficult (Banerjee et al., 2008), financial incentives ineffective (Huillery and Seban, 2015), and any impact that has been found requires local competition which is likely missing in rural parts of the developing world (Callen et al., 2016). Alternative methods of providing community based services or monitoring have shown some promise (Björkman et al., 2009; Banerjee et al., 2010), but a survey of this work finds that social accountability alone cannot change behavior, partially due to a "fear factor" retaliation or withheld services (Fox, 2015).

This paper proposes an alternative to attempting to change the behavior of public sector health workers. Instead, the project focuses on removing uncertainty regarding staff attendance and available services at the local clinic in a rural Ugandan community. Project staff at the public clinic sent SMS messages to a randomly selected subset of cell phone-owning households located throughout the local community confirming either the attendance of a local doctor or clinical officer, or the availability of vaccinations at the clinic. Receipt of these messages was free of charge. This allowed members of the local community to make a decision regarding whether to seek medical care knowing, with certainty, that the care they seek is available. Furthermore, this certainty is created without needing to change the behavior of the staff at the clinic.

The paper utilizes a difference-in-difference approach to identify the impact of the SMS program on a set of randomly selected treatment households, relative to control households. The analysis finds that the SMS messages led to an increase in attendance at the clinic for children six years of age or less, and an increase in clinic attendance due to ongoing illness. Furthermore, the SMS messaging program led to an increased rate of medication received from the clinic for both ongoing illnesses (antibiotics, malaria, and pain medicine) and preventive care (vitamin A and deworming medication), a reduction in the duration of illness by nearly three days, and a reduction in the likelihood of being severely ill for longer than a week. However, these

effects only exist for children who live in households in which an adult of the same sex, and only the same sex, received the SMS messages from the clinic. Encouragingly, there is no evidence of a negative impact on children of the opposite sex of the message recipient.

The benefits described above are the benefits accrued to children who are the same sex as the cell phone owner in households that received SMS clinic updates, relative to those in households that did not receive SMS messages. However, these gains were not only found relative to children of the same sex as cell 
phone owners in control households, they were also found relative to children of the opposite sex in treated households. This is significant evidence of favoritism by the guardians of these children towards children of the same sex. Furthermore, the favoritism persists even when the sample is restricted to compare children of the same and opposite sex of the cell phone owner within the same household. This demonstrates that the favoritism is being exhibited by adults who must make healthcare decisions for both young boys and girls, and that the information from the SMS program is used only to benefit children of the same sex as the message recipient. The benefits of this favoritism are largely balanced for both boys and girls, evidence that it is not sex specific.

Evidence that parents act differently according to the a child's gender has been found in many societies. ${ }^{1}$ For example, in the US, sons increase men's work hours and wages more than daughters (Lundber and Rose, 2002), and fathers tend to spend more time with sons, are more likely to get married and stay married in families with sons, and divorced fathers are more likely to have custody of sons, relative to daughters (Raley and Bianchi, 2006). Evidence from Ethiopia shows that absence of fathers affects boy's survival and growth more than girls' (Gibson, 2008). However, in Côte d'Ivore, when women receive additional income, the height-for-age increases more for boys than for girls (Haddad and Hoddinott, 1994), and evidence from Asia and Africa show that fathers' assets improve with daughter's educational outcomes (Quisumbing and Maluccio, 2003). The current paper finds an increased investment in health for young children of the same sex as the parent receiving SMS updates regarding the clinic, but that the impact is diluted when parents of both sexes receive the messages.

Mobile phone usage in Uganda has rapidly increased in the past decade; in 2006 there were only 7 mobile subscriptions per 100 people in Uganda, in 2014 that number had risen to 52 mobile subscriptions per 100 people (World Bank, 2016). This technology has allowed for increased information sharing. In the field of healthcare, this has previously meant medication reminders and educational healthcare-related messages (Aker and Mbiti, 2010). For monitoring, Callen et al. (2016) increased the number of clinics monitored by enabling reports to be submitted electronically from the clinic. This work combines both ideas by taking advantage of mobile technology to quickly share information, but to share the clinic updates with the local community, not only the project staff.

\section{Background}

The SMS program operated in Nnindye Parish, a rural area of Uganda that borders Lake Victoria. ${ }^{2}$ The parish has a population of approximately 7,000 residents whose primary economic activity is small-scale

\footnotetext{
${ }^{1}$ See Russell and Saebel (1997) for a review of the earlier literature.

${ }^{2}$ The parish is located in Nkozi sub-county, within Mpigi District.
} 
agriculture, and consists of 12 local villages. Nnindye Parish contains a local Level III Health Center which provides free medicine and basic services (such as pre-natal care, family planning methods, immunizations, and basic medication), and is the central focus of this study. The staff at the clinic consisted of a team of nurses, a doctor from the local hospital who visited the clinic weekly, and a clinical officer (i.e. nurse practitioner) who also visited three times per week.

As an alternative to monitoring staff at the local clinic, which previous work has found to be considerably difficult, this project aimed to reduce the cost of attending the clinic by sharing "real-time" information with the local community regarding confirmed clinic activities and staff attendance via SMS messaging. A total of 11 messages providing information on vaccination programs, and attendance of the doctor and clinical officer were sent out over a ten-week period. ${ }^{3}$

Every household in which at least one member owned a cell phone was eligible to participate in the SMS program. Although the average income in the parish was roughly USD $\$ 302$ at the time of the study, 603 of the 1,212 households interviewed at baseline were eligible. Of the 603 eligible households, 314 were randomly selected to receive SMS updates from the clinic, while the remaining cell phone-owning households constituted the control group.

\section{$3 \quad$ Data and Estimation Strategy}

\subsection{Data}

Data collection was conducted in three phases. Household data were collected throughout the parish at two points in time, both prior to and following the completion of the SMS program. A total of 496 of the 603 cell phone-owning households were interviewed in the second wave of the study; an 82.3 percent rate of retention. The remaining data were collected at the clinic. To set a baseline, clinic data collection began three weeks prior to the implementation of the SMS program, and continued throughout the ten weeks of the program. Information was collected on the number of attendees at the clinic on each day, reasons patients attended the clinic, and broad categories of any medication received. The observations of individuals interviewed at the clinic are matched with the household survey to link clinic attendance to other personal characteristics and SMS treatment.

Initial evidence of overall clinic attendance, shown in Figure 1, demonstrates the impact of the SMS program, and previews the statistically significant increase in children visiting the clinic that is also found in the individual results in the following section. Using every day of data for the sample period, the first

\footnotetext{
${ }^{3}$ The entire cost of messaging was borne by the sender; there was no cost to the message recipient.
} 
pair of bars shows the average number of people that visited the clinic on days with an SMS message (dark gray) relative to days without an SMS message (light gray). This demonstrates that, on average, there were ten more people attending the clinic on days that SMS messages announced confirmation of activity or staff attendance at the clinic. ${ }^{4}$ The following two pairs, for days the doctor visited from the local hospital or the clinical officer was present, yield no meaningful difference in attendance for days the SMS message was sent. Finally, the fourth pair of bars includes days during which the clinic provided vaccines for children; attendance was 42 percent higher (62.5 vs. 43.8) on days when SMS messages were sent. As would be expected, attendance for children was also 45 percent higher (35.8 vs. 24.6$)$ on vaccination days with an SMS message. ${ }^{5}$ This evidence suggests that the impact of the SMS program at the individual level is likely to be strongest for children, the group most likely attending the clinic during vaccination days.

Observable characteristics of treatment (SMS) and control (non-SMS) households and individuals are compared in Table 1. The top panel compares baseline statistics for cell phone-owning households. The randomization is balanced across logged household income, number of young children, adults over 31, and number of cell phones in the household. ${ }^{6}$ The subsample of children, age 6 and under, is the age range of children who generally have not yet entered primary school, and will be the focus of much of the paper's analysis in Section 4.

Cell phones are solely owned by either women or men in a similar fraction of both treatment and control households; cell phones are owned by both men and women in remaining households included in the sample. ${ }^{7}$ The sex of the individual receiving the SMS messages will be significant in the following section. Individual characteristics from the baseline household survey are shown at the top of Panel B, for individuals of all ages. Individuals in both treatment and control households are a similar age, equally likely to be female, were sick at a similar rate and for similar duration prior at baseline, and were equally likely to visit the clinic due to illness prior to the messaging program.

The individuals in treated households were 1.8 percentage points more likely to visit the clinic during the three weeks prior to the messaging program. However, this difference was largely driven by individuals age 31 and older (0.085 versus 0.042 ), and there is no evidence that this difference impacted the attendance of young children (0.034 versus 0.032), as seen in Panel C. The remaining statistics in Panel C further compare baseline characteristics of children, age 6 and under, in treatment or control households. These children in these two sets of households were equally likely to have been ill and were ill for a similar duration prior to the baseline survey, they visited the clinic for similar reasons, and there are no statistically differences in

\footnotetext{
${ }^{4}$ This difference is statistically significant at the 90-percent level.

${ }^{5}$ Both increases on vaccination days are statically significant, at the 95-percent level for adults and the 90-percent level for children. A timeline of events for each of these three categories and the SMS messages are shown in Appendix Table A1.

${ }^{6}$ To be included in the study sample the household must own at least one cell phone.

${ }^{7}$ These remaining cell phone-owning households are later referred to as "dual" households.
} 
the type of medication they received from the clinic. The evidence in Table 1 demonstrates a sample that is well balanced between treatment and control across a number of observable characteristics; this is especially true for children age 6 and under.

\subsection{Estimation Strategy}

The main focus of the statistical analysis is to identify changes in clinic attendance and health for individuals in treated households that were randomly assigned to receive SMS messages regarding clinic activity, relative to those who were not. A difference-in-difference (DiD) identification strategy is employed to measure the change in the post-program level of these outcomes, relative to the pre-program levels, for both sets of households. To measure this change, let $\bar{y}^{t p}$ represent the mean outcome of interest for individuals in treated households in the "post-period," after the implementation of the SMS program, and $\bar{y}^{t b}$ be the average of the same outcome for the same treated individuals before the beginning of the messaging program. ${ }^{8}$ The difference between the two means $\left(\bar{y}^{t p}-\bar{y}^{t b}\right)$ is the change in the outcome of interest in treated households following the implementation of the SMS program. However, this change could be due to general changes in the parish or clinic that impact all households, not just those treated by the SMS program. Additionally, post-treatment data from the clinic were collected during a longer time period; therefore, it is more likely that people were seen at the clinic during the post-SMS period relative to the pre-program monitoring period. To take these potential differences into account, the same post-SMS minus pre-SMS comparison is made for the control set of households $\left(\bar{y}^{c p}-\bar{y}^{c b}\right)$. The control households also own cell phones, but were randomly selected not to receive clinic updates via SMS. The difference for the control households captures any changes impacting all patients at the clinic, or all members of the local community. The difference of these two differences,

$$
\hat{\beta}=\left(\bar{y}^{t p}-\bar{y}^{t b}\right)-\left(\bar{y}^{c p}-\bar{y}^{c b}\right)
$$

yields the isolated change in the outcome of interest that is unique to the treated group, and takes into account any general change that also affected the control households. This is the impact of the SMS program, the treatment, on the outcome of interest, $y$.

The above DiD strategy can be rewritten as a linear ordinary least square regression model of the following form:

$$
y_{i h t}=\alpha+S M S_{h} \text { Post }_{t} \beta+S M S_{h} \tau+\text { Post }_{t} \theta+\varepsilon_{i h t} .
$$

The dependent variable is $y$, for individual $i$, in household $h$, and time period $t$. Each individual in the sample was observed twice, once prior to and once following the implementation of SMS messaging program, and resides in a household that owns a cell phone. The $S M S_{h}$ variable is an indicator variable equal to

\footnotetext{
${ }^{8}$ The illustrative description of the difference-in-difference model is motivated by Cristia et al. (2015).
} 
one if the household received SMS messages regarding clinic staff, and zero otherwise. Post $t_{t}$ is an indicator variable equal to one for all observations from the post-messaging period, and zero otherwise. The DiD estimator is again $\beta$, and yields the same DiD estimation generated by equation (1). ${ }^{9}$

A benefit of utilizing the regression framework is the model's ability to account for differences in observable characteristics;

$$
y_{i h t}=\alpha+S M S_{h} \text { Post }_{t} \beta+S M S_{h} \tau+\text { Post }_{t} \theta+X_{i h t} \delta+\varepsilon_{i h t} .
$$

$X_{i h t}$ is a vector of observable individual and household characteristics. This includes a quadratic control for age, an indicator equal to one if the individual is male, logged household income during the baseline survey, and a set of fixed effects for the village of residence to take into account both community characteristics and distance to the clinic.

Much of this paper focuses on who specifically benefits from the type of information shared in the SMS messages. This is done by estimating equation (3) specifically for individuals who are the same sex as the SMS recipient (i.e. cell phone owner), and generating a separate estimate for those who are a different sex for the SMS recipient. Estimates from equation (3) find evidence of favoritism towards young children who are of the same sex as the cell phone owner. It is then important to determine if the advantage gained by this favoritism is statistically significant. This is done by first estimating the DiD model for individuals who are the same sex as the cell phone owner $\left(\hat{\beta}_{s}\right)$; this measures the benefit to these individuals in households which received SMS updates relative to those in households who did not. The estimation is then repeated for individuals who are of the opposite sex of the cell phone owner $\left(\hat{\beta}_{d}\right)$. These two estimates can then be compared to determine whether individuals of the same sex as the cell phone owner are better or worse off than those who are of the opposite sex of the cell phone owner. This is calculated using the DiD estimators from equation (1) to construct a triple-difference:

$$
\hat{\beta}^{t r i p l e}=\hat{\beta}_{s}-\hat{\beta}_{d}=\left[\left(\bar{y}_{s}^{t p}-\bar{y}_{s}^{t b}\right)-\left(\bar{y}_{s}^{c p}-\bar{y}_{s}^{c b}\right)\right]-\left[\left(\bar{y}_{d}^{t p}-\bar{y}_{d}^{t b}\right)-\left(\bar{y}_{d}^{c p}-\bar{y}_{d}^{c b}\right)\right]
$$

The triple difference estimator $\left(\hat{\beta}^{\text {triple }}\right)$ is calculated by taking the difference of two DiD estimators $\left(\hat{\beta}_{s}\right.$ and $\left.\hat{\beta}_{d}\right)$. Often times this is comparing individuals, or siblings, within the same household. When the sample is restricted to children, a positive estimate of $\hat{\beta}^{\text {triple }}$ would measure the gain for children of the same sex as the cell phone owner relative to children, or siblings, of the opposite sex. ${ }^{10}$ This triple-difference estimator

\footnotetext{
${ }^{9}$ All regressions cluster standard errors at the level of randomization, the household, to allow for within-household correlation in the error term overtime (Bertrand et al., 2004).

${ }^{10}$ Results in Appendix Table A3 are estimated using only households with children of both sexes to explicitly make the comparison between siblings. The main analysis takes advantage of the expanded sample size from including all households; the results are qualitatively and quantitatively similar.
} 
can also be expressed as a regression of the following form:

$$
\begin{aligned}
y_{i h t}= & \alpha+\text { Same }_{i} \text { SMS }_{h} \text { Post }_{t} \beta^{\text {triple }}+\text { SMS }_{h} \text { Post }_{t} \sigma_{1}+\text { Same }_{i} \text { Post }_{t} \sigma_{2}+\text { Same }_{i} \text { SMS }_{h} \sigma_{3} \\
& + \text { SMS }_{h} \tau+\text { Post }_{t} \theta+\text { Same }_{i} \gamma+X_{i h t} \delta+\varepsilon_{i h t} .
\end{aligned}
$$

$\hat{\beta}^{\text {triple }}$ is analogous to the estimator from equation (4), and can be interpreted as the difference between effect of the SMS program on individuals of the same sex as the cell phone owner and the effect of the program on those of the opposite sex of the cell phone owner. Same $e_{i}$ is an indicator equal to one if the individual is the same sex as the cell phone owner, and an additional indicator that is equal to one if a male owns the household cell phone is added to the $X_{i h t}$ vector. ${ }^{11}$

\section{Results}

\subsection{Clinic Attendance}

Figure 2 displays the fraction of children aged 6 and under that attended the local government run clinic either prior to the SMS program (light gray), or following the program's implementation (dark gray). This information is shown for treatment (SMS) households and control (no SMS) households, across three separate sets of observations. The information displayed furthest to the left in Figure 2 is the attendance rate for "same" children, those who are the same sex as the cell phone owner (i.e. boys in households where only men own a cell phone, or girls in households where only women own a cell phone). ${ }^{12}$ With this information, the DiD estimate from equation (1) can be estimated for children of the same sex as the cell phone owner in their household. For these children, the increase in the clinic attendance rate in the 10 weeks following the implementation of the SMS program, relative to the three weeks prior to the program, was 30 percentage points $\left[\bar{y}^{t p}-\bar{y}^{t b}=0.326-0.022=0.304\right]$. Some portion of this increase was due to the extended post-program time period, and possibly more general changes in clinic perception, or rate of illness in the local parish. However, any of these explanations would also affect control households. The increase in the rate of clinic attendance for "same" children in control households is 9 percentage points $\left[\bar{y}^{c p}-\bar{y}^{c b}=0.133-0.040=0.093\right]$. Finally, the difference in the two rates of increase, the DiD measure, is $\hat{\beta}=0.211$. Children who are the same sex as the SMS message recipient in treatment households were 21

\footnotetext{
${ }^{11}$ The cell phone ownership indicator is not included in equation (4) because including the male indicator perfectly identifies the sex of the cell phone owner when the sample is separated by whether the individual is of the same or opposite sex of the cell owner.

${ }^{12}$ This sample consists of 120 unique households. 70 households in which only men own a phone, and 50 in which only women own a phone. In 28 of the households, multiple men own a cell phone; in 24 households, more than one woman owns a cell phone.
} 
percentage points more likely to attend the clinic during the program than children who are the same sex as the cell phone owner in the control households. On average, the only difference between these households is that treated households intermittently received confirmation that the doctor or clinical officer would be at the clinic, or most importantly, confirmation of days that vaccinations would be offered at the clinic. It is likely that control households were aware of these messages as well, but any extent to which this occurred would have only increased the likelihood of post-SMS attendance of individuals in control households. This additional attendance would increase the "control difference", biasing the estimate downwards, and leading to a reduction in the DiD estimate.

The same method can be used to find the DiD estimate for the other two groups in Figure 2. The point estimates for all three of the subsamples used in Figure 2 are shown in the top row of Table 2. The DiD estimates in Table 2 are calculated using equation (3), with a full set of controls. Each estimate is from a separate regression. The estimate in the top left of the table corresponds to the estimate calculated in the preceding paragraph, for "same" children aged 0 to 6 ; the estimate is statistically significant at the 95 percent level. ${ }^{13}$ The estimate in column (2) of the top row is for children in the same age range who are of the opposite sex of the cell phone owner. These children do not see the same increase in clinic attendance, but, importantly, the negative point estimate is small and not statistically significant. This suggests there is no direct negative impact on children of the opposite sex of the message recipient. Column (3) estimates the effect for young children in "dual" households, households in which at least one cell phone is owned by a man and another by a woman. This ensures that all children have an adult of their sex who receives the SMS messages. For young children in these households, the estimated impact of the SMS program is positive, like the estimate seen for "same" children, but not statistically significant at the 90 percent level. Interestingly, the estimate falls between the estimate for children the same sex as the cell phone owner, and children of the opposite sex.

The fourth column uses equation (5) to estimate the triple-difference, the difference between the effect of the SMS program on children who are of the same sex as the cell phone owner, column (1), and those of the opposite sex, column (2). The model estimates that SMS program increased clinic attendance for children of the same sex as the cell phone owner, relative to children of the opposite sex, by 24 percentage points. This is evidence that the message recipient demonstrated significant favoritism towards children of the same sex. In fact, when the sample is restricted to children within the same household, the relative benefit for "same" children increases to a statistically significant 30 percentage points. ${ }^{14}$ The estimate in column (3), and its magnitude relative to the estimates in the first two columns, suggest that this favoritism is attenuated when

\footnotetext{
${ }^{13}$ The difference in the third decimal place is due to rounding of the values included in Figure 2.

${ }^{14}$ The point-estimate can be found in column (3) of Appendix Table A3
} 
parents of both sexes own a cell phone.

The following three rows of results repeat the same set of estimates for children who are primary school age, 7 to 14 , and the remaining sample is split into roughly equal sizes, 15 to 30-year-olds and those 31 years of age and older. The 12 estimates in the bottom three rows of the table are generally small, and consistently not statistically significant. The pattern in column (4), that there is some relative benefit to those who are the same sex as the message recipient, remains at least nominally positive for all age ranges. The isolation of the impact on young children is not surprising after seeing Figure 1, which finds the increase in attendance at the clinic isolated to vaccination days. This suggests that parents may be taking advantage of the SMS updates to attend the clinic on days that they know their children will get maximum attention. The remainder of the paper focuses on the type of medical care received by the young children who were impacted by the messaging program, and whether this attendance did in fact lead to any measurable health benefit.

\subsection{Services Received at the Clinic}

The estimates in Table 3 focus on the reason that parents took their young children to the clinic during the SMS program, and what type of care they received. The first three columns of the table are separated into the same three types of observations used the Table 2. Like Table 2, the results in Table 3 find a similar pattern: large increases for "same" children in treated households, both relative to control households and children of the opposite sex of the cell phone owner. There is also evidence of an impact on children of the opposite sex, and an attenuated effect for children in "dual" households that yields a point-estimate between the estimates in the first two columns. Furthermore, evidence in column (5) also shows that the favoritism towards children of the same sex exists even when the sample is restricted to households that have both boys and girls; in these households, the adults are directly choosing to increase healthcare take-up for children of their sex over children of the opposite sex.

The outcome in Panel A is equal to one if an individual visited the clinic because of illness, and zero otherwise. "Same" children in treated households are 12.6 percentage points more likely to have visited the clinic due to illness than those in control households, and 13.9 percentage points more likely than children of the opposite sex of the message recipient. This advantage is even larger within households that have both boys and girls. The estimates in Panel B, for attending the clinic to receive vaccination, are not statistically significant in the first four columns. However, these estimates do follow the same pattern as the other clinic attendance variables, and are positive for "same" children, as suggested by Figure 1. Again, a larger and statistically significant advantage is found for "same" children relative to children of the opposite sex in their 
household.

A similar pattern can be seen in the type of medication received, Panel C and Panel D. The outcome in Panel C, medication for illness, is equal to one if a child received antibiotics, malaria medication, or pain medication during a clinic visit, and zero otherwise. Preventive medication, Panel $\mathrm{D}$, is equal to one if the child received either vitamin A supplements or deworming medication at the clinic, and zero otherwise. All medication from the clinic is provided at no cost to the patient. The estimates in Panel D are only a post-treatment comparison of treatment and control groups, there was no information gathered on these medications prior to the SMS program. The SMS program led to an increase in both medicine for illness and preventive medication received for "same" children in treated households, relative to both "same" children in control households, column (1), and "different" children in treated households, columns (4) and (5). The effect of the SMS program for children in "dual" households again falls between the estimates in the first two columns, again showing evidence of a diluted effect in the same direction as the estimates in column (1). Furthermore, not only did the messaging program increased the likelihood of "same" children attending the clinic, the estimates in Table 3 find that the program also increased the likelihood of receiving medication while at the clinic.

\subsection{Health Outcomes}

The previous sets of results find evidence that young children who are the same sex as the adult(s) in their household who received the SMS clinic updates are more likely to attend the local clinic and receive medication; the estimates in Table 4 examine whether the SMS program also generated health benefits. The outcome in Panel A is equal to one if a child has been sick in the last 30 days, zero otherwise. The outcome in Panel B is the number of days sick out of the last 30, and in Panel $\mathrm{C}$ is an indicator equal to one if an individual was incapacitated, unable to partake in usual day-to-day activities, for over a week in the last month. As seen in Table 3, only "same" children attended the clinic more often due to illness and are more likely to receive medication for illness.

The results in Table 4 find evidence that these children are also more likely to be healthy at the end of the SMS messaging program. The results in column (1) of Panel A find an 18.7 percentage point decline in the likelihood of being ill in the last 30 days, with a t-statistics of 1.59 and a p-value of 0.114 , relative to "same" children in control households. Although large, this estimate is smaller than the increase in clinic attendance, placing the magnitude in the range of plausible outcomes. The $\mathrm{DiD}$ estimates in the first column of Panel B also find a reduction of 2.9 days sick, and a 12.3 percentage point decline in the likelihood of being incapacitated for more than a week. This reduction is isolated to only children in treated households, 
who are the same sex as the cell phone owner, and where there is only a single sex of cell phone ownership. The post-treatment information on illness was collected at the end of the program, and all clinic information used in Table 2 and Table 3 was collected during the 10 weeks of the program. This timing suggests that the clinic visits led to improvements in health for the "same" category of children. Furthermore, the estimates in columns (4) and (5) show that these improvements also exist relative to children in the treated households, but of the opposite sex from the message recipient. Again, evidence of favoritism of the message recipient towards children of the same sex.

\subsection{Favoritism: Boys versus Girls}

To this point, estimates have combined both boys and girls into the same set of regressions, and found that if a child is the same sex as the cell phone owner, he/she benefits from the SMS program in terms of clinic attendance, receipt of medication while at the clinic, and improved health. To investigate if favoritism of a single gender is driving these findings, the estimates in Table 5 are shown separately for "same" boys and girls. The outcomes from the previous three tables are examined. The point estimates use the same DiD approach described in equation (3) to compare the outcome of interest for the specified sex in treated households, boys in column (1) and girls in column (2), to those in control households who are also the same sex as the cell phone owner. The SMS program led to statistically significant increases in the likelihood of attending the clinic (Panel A) and receiving preventive medicine (Panel E) for both boys and girls. The SMS program led to improvements across the six remaining measures for both boys and girls; however, the estimates for girls tend to be more precise. Girls also see larger improvements in attending the clinic due to illness, receiving medication for the illness, and are less likely to be severely ill. The evidence in Table 5 demonstrates that the favoritism shown to children of the same sex exists for both boys and girls, with suggestive evidence of a slightly larger effect for girls in households in which only women own a cell phone.

\section{Conclusion}

A randomized evaluation was used to measure the impact of an SMS messaging program on healthcare utilization and health in a rural area of Uganda. Among households that owned a cell phone, a random group was selected to receive SMS updates regarding services available at the local health clinic such as vaccinations and clinic staff. Data from clinic attendance and two household surveys were used in a difference-in-difference model to evaluate the impact of the SMS program.

The findings revealed that on days with an SMS message, clinic attendance was higher, relative to days without SMS updates. In particular, the analysis finds that the SMS messages led to an increase in 
attendance at the clinic for children six years of age or less, and an increased rate of medication received from the clinic for both ongoing illnesses and preventive care. However, these effects only exist for children who live in households in which an adult of the same sex, and only the same sex, received the SMS from the clinic. Furthermore, the SMS program led to a reduction in the duration and severity of illness for these same children. These benefits were found relative to both children of the same sex as cell phone owners in control households and children of the opposite sex in treatment households. The evidence suggests that in Uganda, mother-daughter and father-son relationships are likely stronger than cross-sex parent-child relationships. Even though the benefits of the clinic information are isolated to children of the same sex as cell phone owners, there is no evidence of a negative impact on children of the opposite sex from the message recipient.

This work provides an original and unique method to increase healthcare take-up in developing parts of the world. When evaluating the decision to consume healthcare, an individual must weight the benefits, which include some non-zero probability of receiving the needed care, against the costs, such as the journey to the clinic. Alternative programs have found success in increasing number of medical professionals available to rural communities by hiring NGOs to provide mobile medical teams (Cristia et al., 2015). This program, like monitoring (Banerjee et al., 2008; Callen et al., 2016; Björkman et al., 2009) and health education (Mo et al., 2014), attempts to increase the perceived benefit of accessing the existing healthcare network. Monitoring achieves this by attempting to increase the likelihood that the service is actually available at the clinic after an individual has made the decision to seek care. Health education seeks to increase the consumer's ex-ante understanding of the benefits of healthcare. These benefits are often difficult for an individual to verify with their own experience due to the fact that the benefit is often preventing illness from occurring. Although both of these types of programs are important and can be effective, this work attempts to simply address uncertainty of healthcare availability. This proves to be a powerful tool because unlike the benefits of healthcare itself, individuals who receive updates of clinic activities can verify the information with their own experience. Receiving SMS updates and verifying their validity by finding the service or staff available at the clinic allows individuals participating in the SMS program to increase their perceived benefit of healthcare consumption by significantly increasing the likelihood that the care they seek is available.

Given the rapid growth of cell phone ownership in Uganda, and throughout much of the developing world, this program offers a low-cost framework on which an effective public and private partnership can be built. This type of program can allow public clinics to interact and build trust with their local community by providing information on the availability of staff, services, and even medicines. This information can promptly be verified by the local community, and allows participants to update their beliefs regarding the availability of local services. Furthermore, the program takes advantage of technological expansion to directly connect services with the local community, without the need for permanent external involvement. This type 
of program can create a sustainable improvement to any local community in which cell phones are widely available and information can quickly be shared. 


\section{References}

Aker, J. C. and Mbiti, I. M. (2010). Mobile Phones and Economic Development in Africa. Journal of Economic Perspectives, 24(3):207-232.

Banerjee, A. V., Banerji, R., Duflo, E., Glennerster, R., and Khemani, S. (2010). Pitfalls of Participatory Programs: Evidence from a Randomized Evaluation in Education in India. American Economic Journal: Economic Policy, 2(1):1-30.

Banerjee, A. V., Duflo, E., and Glennerster, R. (2008). Putting a Band-Aid on a Corpse: Incentives for Nurses in the Indian Public Health Care System. Journal of the European Economic Association, 6(2-3):487-500.

Bertrand, M., Duflo, E., and Mullainathan, S. (2004). How Much Should We Trust Differences-In-Differences Estimates? Quarterly Journal of Economics, 119(1):249-275.

Björkman, M., Svensson, J., et al. (2009). Power to the People: Evidence from a Randomized Field Experiment on Community-Based Monitoring in Uganda. Quarterly Journal of Economics, 124(2):735-769.

Callen, M., Gulzar, S., Hasanain, A., and Khan, Y. (2016). The Political Economy of Public Sector Absence: Experimental Evidence from Pakistan. Working Paper.

Chaudhury, N., Hammer, J., Kremer, M., Muralidharan, K., and Rogers, F. H. (2006). Missing in Action: Teacher and Health Worker Absence in Developing Countries. Journal of Economic Perspectives, 20(1):91116.

Cristia, J., Evans, W. N., and Kim, B. (2015). Improving the Health Coverage of the Rural Poor: Does Contracting-Out Mobile Medical Teams Work? The Journal of Development Studies, 51(3):247-261.

Fox, J. A. (2015). Social Accountability: What Does the Evidence Really Say? World Development, $72: 346-361$.

Fujita, M., Roth, E. A., Lo, Y.-J., Hurst, C., Vollner, J., and Kendell, A. (2012). Low Serum Vitamin A Mothers Breastfeed Daughters More Often Than Sons in Drought-ridden Northern Kenya: A Test of the Trivers-Willard Hypothesis. Evolution and Human Behavior, 33(4):357-364.

Gibson, M. A. (2008). Does Investment in the Sexes Differ When Fathers Are Absent? Sex-biased Infant Survival and Child Growth in Rural Ethiopia. Human Nature, 19(3):263-276.

Goldstein, M., Graff Zivin, J., Habyarimana, J., Pop-Eleches, C., and Thirumurthy, H. (2013). The Effect of Absenteeism and Clinic Protocol on Health Outcomes: The Case of Mother-to-Child Transmission of HIV in Kenya. American Economic Journal: Applied Economics, 5(2):58-85. 
Haddad, L. and Hoddinott, J. (1994). Women's Income and Boy-girl Anthropometric Status in the Côte d'Ivoire. World Development, 22(4):543-553.

Huillery, E. and Seban, J. (2015). Financial Incentives are Counterproductive in Non-Profit Sectors: Evidence from a Health Experiment. Working Paper.

Lundber, S. and Rose, E. (2002). The Effect of Sons and Daughters on Men's Labor Supply and Wages. Review of Economics and Statistics, 84(2):251-268.

Mo, D., Luo, R., Liu, C., Zhang, H., Zhang, L., Medina, A., and Rozelle, S. (2014). Text Messaging and its Impacts on the Health and Education of the Poor: Evidence from a Field Experiment in Rural China. World Development, 64:766-780.

Quisumbing, A. R. and Maluccio, J. A. (2003). Resources at Marriage and Intrahousehold Allocation: Evidence from Bangladesh, Ethiopia, Indonesia, and South Africa. Oxford Bulletin of Economics and Statistics, 65(3):283-327.

Raley, S. and Bianchi, S. (2006). Sons, Daughters, and Family Processes: Does Gender of Children Matter? Annual Review of Sociology, 32:401-421.

Russell, A. and Saebel, J. (1997). Mother-son, Mother-daughter, Father-son, and Father-daughter: Are They Distinct Relationships? Developmental Review, 17(2):111-147.

World Bank (2016). World Bank Open Data. Data retrieved August 23, 2016 from data.worldbank.org. 


\section{Figures}

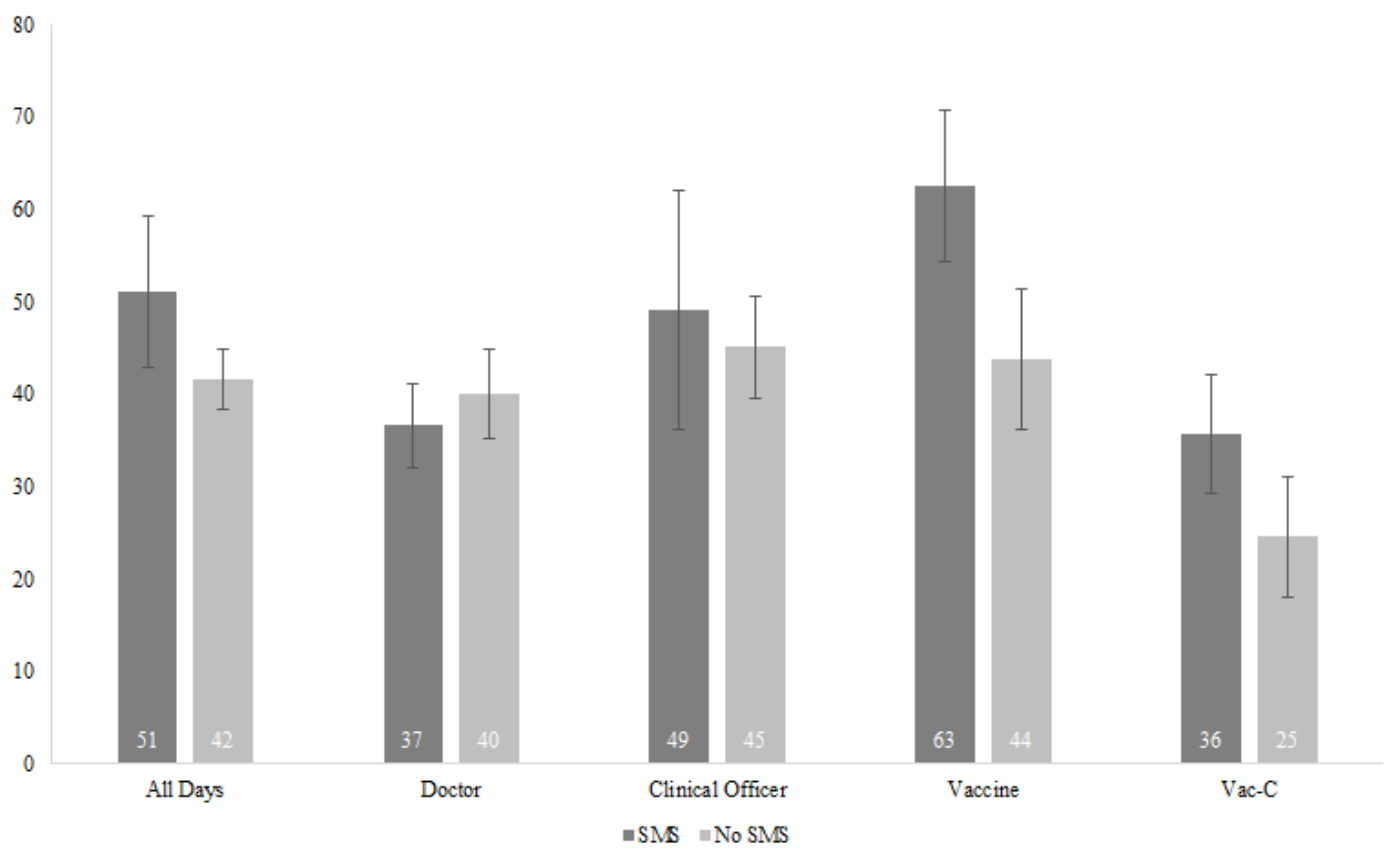

Note: 90-percent confidence bars are shown.

Figure 1: Number of Clinic Attendees

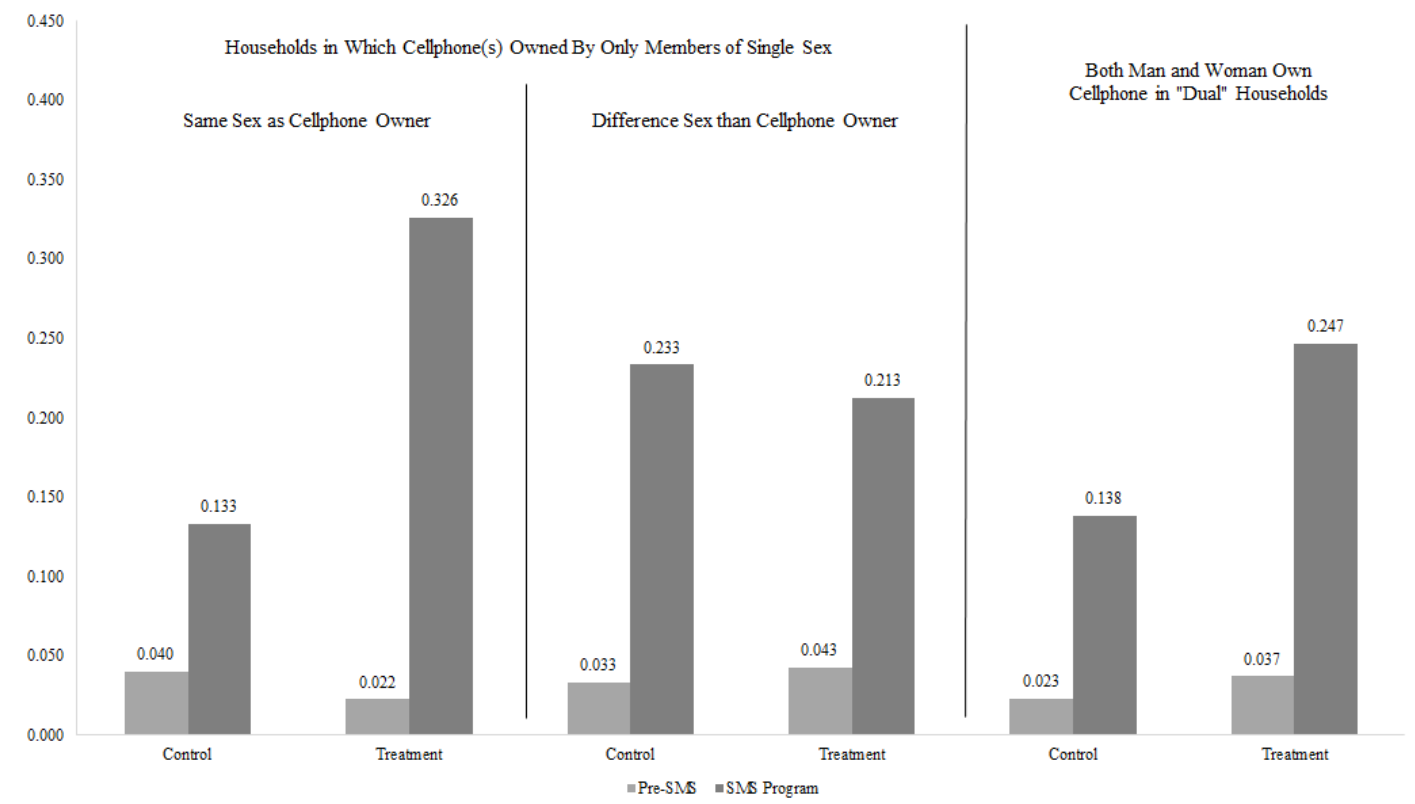

Figure 2: Fraction of Children Aged 6 and Under Visiting the Clinic 


\section{Tables}

Table 1: Summary Statistics: Pre-SMS Program

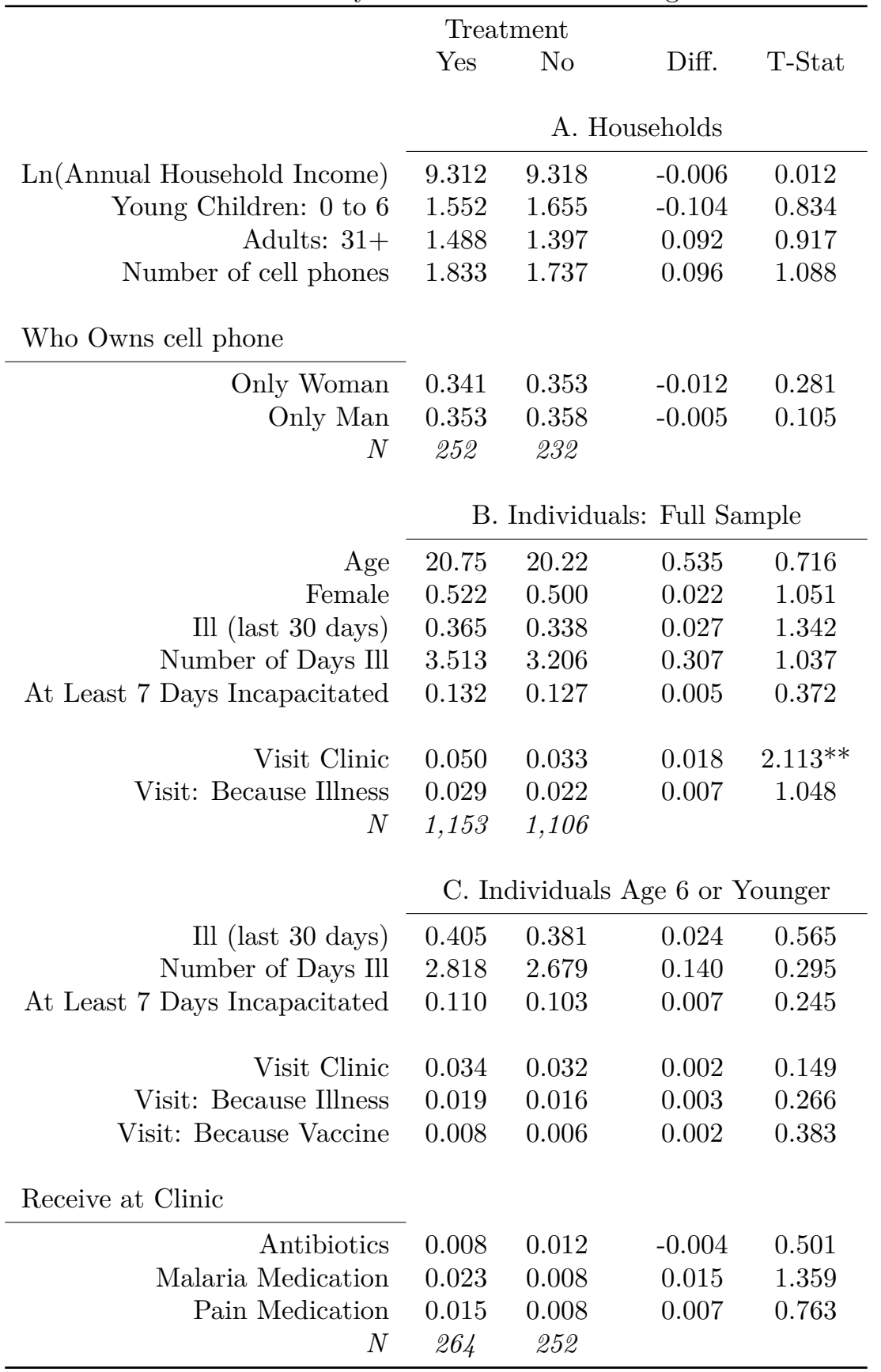

Note: ${ }^{* * *} \mathrm{p}<0.01,{ }^{* *} \mathrm{p}<0.05,{ }^{*} \mathrm{p}<0.1$. Baseline data on household income and number of household members, and individual age, sex, and illness status are the first round (pre-SMS messaging program) of the household survey. Baseline data on clinic visits and medication are from exit interviews at the local health clinic taken during the three weeks prior to the SMS program; clinic data were then linked to the household dataset to determine treatment status of each individual's household. 
Table 2: Effect of SMS Program on Clinic Visits

\begin{tabular}{|c|c|c|c|c|}
\hline & $\begin{array}{r}\text { Sex R } \\
\text { cell ph }\end{array}$ & $\begin{array}{l}\text { ive to } \\
\text { Owner }\end{array}$ & $\begin{array}{l}\text { Both Man and } \\
\text { Woman Own }\end{array}$ & Difference \\
\hline & Same & Different & & $(1)-(2)$ \\
\hline & (1) & (2) & (3) & (4) \\
\hline Age & & & & \\
\hline 0 to 6 & $0.210^{* * *}$ & -0.030 & 0.095 & $0.240^{* *}$ \\
\hline & $(0.068)$ & $(0.080)$ & $(0.066)$ & $(0.093)$ \\
\hline$N$ & 328 & 368 & 336 & 696 \\
\hline 7 to 14 & 0.035 & -0.020 & -0.041 & 0.055 \\
\hline & $(0.029)$ & $(0.025)$ & $(0.034)$ & $(0.033)$ \\
\hline$N$ & 472 & 412 & 392 & 884 \\
\hline 15 to 30 & 0.020 & -0.044 & -0.031 & 0.064 \\
\hline & $(0.039)$ & $(0.057)$ & $(0.050)$ & $(0.070)$ \\
\hline$N$ & 436 & 294 & 374 & 730 \\
\hline $31+$ & -0.027 & -0.028 & 0.008 & 0.001 \\
\hline$N$ & $\begin{array}{c}(0.044) \\
478\end{array}$ & $\begin{array}{c}(0.065) \\
230\end{array}$ & $\begin{array}{c}(0.066) \\
398\end{array}$ & $\begin{array}{c}(0.076) \\
708\end{array}$ \\
\hline & 410 & 200 & 398 & 100 \\
\hline
\end{tabular}

Note: ${ }^{* * *} \mathrm{p}<0.01,{ }^{* *} \mathrm{p}<0.05,{ }^{*} \mathrm{p}<0.1$. The dependent variable in an indicator equal to one if the individual visited the local health clinic, and zero otherwise. The estimates shown in columns (1) to (3) are for the coefficient $(\beta)$ on the interaction between the indicator variable for receiving SMS messages $\left(S M S_{h}\right)$ and the post-SMS indicator $\left(\right.$ Post $\left._{t}\right)$, from equation (3). Estimates in column (4) are for the coefficient on the triple interaction $\left(\beta^{\text {triple }}\right)$ in equation (5). The vector of control variables $\left(X_{i h t}\right)$ in each equation includes a quadratic for age, an indicator variable for male, the natural log of household income, and a set of village specific fixed effects. Each estimate is from a separate regression and is clustered at the household level. 
Table 3: Effect of SMS Program on Reason for, and Type of Care During, Clinic Visits: Children 0 to 6 Years Old

\begin{tabular}{|c|c|c|c|c|c|}
\hline & \multirow{3}{*}{\multicolumn{2}{|c|}{$\begin{array}{l}\text { Sex Relative to } \\
\text { cell phone Owner }\end{array}$}} & \multirow{5}{*}{$\begin{array}{c}\text { Both Man and } \\
\text { Woman Own } \\
\text { cell phone } \\
(3)\end{array}$} & \multicolumn{2}{|c|}{ Difference } \\
\hline & & & & \multirow{3}{*}{$\begin{array}{l}\text { Full Sample } \\
\quad(1)-(2)\end{array}$} & \multirow{3}{*}{$\begin{array}{l}\text { Only HH with } \\
\text { both Boys/Girls } \\
\text { Same - Diff. }\end{array}$} \\
\hline & & & & & \\
\hline & Same & Different & & & \\
\hline & (1) & $(2)$ & & $(4)$ & $(5)$ \\
\hline & \multicolumn{5}{|c|}{ A. Visited Clinic Because of Illness } \\
\hline \multirow[t]{2}{*}{$S M S_{h} *$ Post $_{t}$} & $\begin{array}{c}0.126^{* * *} \\
(0.039)\end{array}$ & $\begin{array}{l}-0.013 \\
(0.046)\end{array}$ & $\begin{array}{c}0.026 \\
(0.038)\end{array}$ & $\begin{array}{c}0.139 * * \\
(0.059)\end{array}$ & $\begin{array}{l}0.180^{*} \\
(0.075)\end{array}$ \\
\hline & \multicolumn{5}{|c|}{ B. Visited Clinic for Vaccine } \\
\hline \multirow[t]{2}{*}{$S M S_{h} *$ Post $_{t}$} & $\begin{array}{c}0.091 \\
(0.063)\end{array}$ & $\begin{array}{l}-0.040 \\
(0.073)\end{array}$ & $\begin{array}{c}0.069 \\
(0.060)\end{array}$ & $\begin{array}{c}0.132 \\
(0.083)\end{array}$ & $\begin{array}{l}0.158^{*} \\
(0.088)\end{array}$ \\
\hline & \multicolumn{5}{|c|}{ C. Received Medicine for Illness at the Clinic } \\
\hline$S M S_{h} *$ Post $_{t}$ & $0.092^{* *}$ & -0.033 & 0.026 & $0.125^{* * *}$ & $0.128^{*}$ \\
\hline \multirow[t]{2}{*}{$N$} & $\begin{array}{c}(0.036) \\
328\end{array}$ & $\begin{array}{c}(0.033) \\
368\end{array}$ & $\begin{array}{l}(0.038) \\
336\end{array}$ & $\begin{array}{c}(0.048) \\
696\end{array}$ & $\begin{array}{l}(0.065) \\
322\end{array}$ \\
\hline & \multicolumn{5}{|c|}{ D. Received Preventative Medicine at the Clinic } \\
\hline$S M S_{h}$ & $\begin{array}{c}0.237^{* * *} \\
(0.074)\end{array}$ & $\begin{array}{c}0.011 \\
(0.063)\end{array}$ & $\begin{array}{c}0.060 \\
(0.062)\end{array}$ & $\begin{array}{c}0.231^{* * *} \\
(0.078)\end{array}$ & $\begin{array}{l}0.175^{*} \\
(0.093)\end{array}$ \\
\hline$N$ & 164 & 184 & 168 & 348 & 161 \\
\hline
\end{tabular}

Note: ${ }^{* * *} \mathrm{p}<0.01,{ }^{* *} \mathrm{p}<0.05,{ }^{*} \mathrm{p}<0.1$. The dependent variable in each panel is an indicator equal to one if the statement in the panel heading is true, and zero otherwise. The estimates shown in columns (1) to (3) of Panels A to $\mathrm{C}$, are for the coefficient $(\beta)$ on the interaction between the indicator variable for receiving SMS messages $\left(S M S_{h}\right)$ and the post-SMS indicator $\left(\right.$ Post $\left._{t}\right)$, from equation (3). Estimates in columns (4) and (5) of Panels A to $\mathrm{C}$ are for the coefficient on the triple interaction $\left(\beta^{\text {triple }}\right)$ in equation (5). Estimates in Panel $\mathrm{D}$ are for the coefficient on the treatment indicator and only include post-SMS observations; the estimate in columns (4) and (5) of Panel D use a DiD estimate to compare columns (1) and (3). The vector of control variables $\left(X_{i h t}\right)$ in each equation includes a quadratic for age, an indicator variable for male, the natural log of household income, and a set of village specific fixed effects. Each estimate is from a separate regression and is clustered at the household level. 
Table 4: Effect of SMS Program on Health: Children 0 to 6 Years Old

\begin{tabular}{|c|c|c|c|c|c|}
\hline & \multirow{2}{*}{\multicolumn{2}{|c|}{$\begin{array}{l}\text { Sex Relative to } \\
\text { cell phone Owner }\end{array}$}} & \multirow{4}{*}{$\begin{array}{c}\text { Both Man and } \\
\text { Woman Own } \\
\text { cell phone }\end{array}$} & \multicolumn{2}{|c|}{ Difference } \\
\hline & & & & \multirow{2}{*}{$\begin{array}{l}\text { Full Sample } \\
\quad(1)-(2)\end{array}$} & \multirow{2}{*}{$\begin{array}{l}\text { Only HH with } \\
\text { both Boys/Girls } \\
\text { Same - Diff. }\end{array}$} \\
\hline & Same & Different & & & \\
\hline & (1) & $(2)$ & & (4) & (5) \\
\hline \multicolumn{6}{|c|}{ A. Ill In Last 30 Days } \\
\hline$S M S_{h} *$ Post $_{t}$ & $\begin{array}{l}-0.187 \\
(0.118)\end{array}$ & $\begin{array}{l}-0.063 \\
(0.103)\end{array}$ & $\begin{array}{c}0.024 \\
(0.132)\end{array}$ & $\begin{array}{l}-0.125 \\
(0.138)\end{array}$ & $\begin{array}{l}-0.055 \\
(0.174)\end{array}$ \\
\hline \multicolumn{6}{|c|}{ B. Days Ill in Last 30 Days } \\
\hline$S M S_{h} *$ Post $_{t}$ & $\begin{array}{c}-2.947^{* *} \\
(1.266)\end{array}$ & $\begin{array}{c}0.479 \\
(1.208)\end{array}$ & $\begin{array}{c}1.547 \\
(1.427)\end{array}$ & $\begin{array}{c}-3.426^{* *} \\
(1.568)\end{array}$ & $\begin{array}{l}-3.718^{*} \\
(2.040)\end{array}$ \\
\hline \multicolumn{6}{|c|}{ C. Incapacitated Due to Illness at Least 7 Days in Last 30} \\
\hline$S M S_{h} *$ Post $_{t}$ & $\begin{array}{l}-0.123^{*} \\
(0.065)\end{array}$ & $\begin{array}{c}0.043 \\
(0.063)\end{array}$ & $\begin{array}{c}0.032 \\
(0.086)\end{array}$ & $\begin{array}{c}-0.166^{* *} \\
(0.083)\end{array}$ & $\begin{array}{l}-0.188^{*} \\
(0.107)\end{array}$ \\
\hline$N$ & 328 & 368 & 336 & 696 & 322 \\
\hline
\end{tabular}

Note: ${ }^{* * *} \mathrm{p}<0.01,{ }^{* *} \mathrm{p}<0.05,{ }^{*} \mathrm{p}<0.1$. The dependent variables in Panel $\mathrm{A}$ and Panel $\mathrm{C}$ are indicators equal to one if the statement in the panel heading is true, and zero otherwise. The dependent variable in Panel B is equal to the number of days, out of the last 30, the individual was ill. The estimates shown in columns (1) to (3) are for the coefficient $(\beta)$ on the interaction between the indicator variable for receiving SMS messages $\left(S M S_{h}\right)$ and the post-SMS indicator $\left(\right.$ Post $\left._{t}\right)$, from equation (3). Estimates in columns (4) and (5) are for the coefficient on the triple interaction $\left(\beta^{\text {triple }}\right)$ in equation (5). The vector of control variables $\left(X_{i h t}\right)$ in each equation includes a quadratic for age, an indicator variable for male, the natural log of household income, and a set of village specific fixed effects. Each estimate is from a separate regression and is clustered at the household level. 
Table 5: Effect of SMS Program: Children 0 to 6 Years Old, by Sex

\begin{tabular}{|c|c|c|}
\hline & \multicolumn{2}{|c|}{ Same Sex as cell phone Owner } \\
\hline & Boys & Girls \\
\hline & $(1)$ & $(2)$ \\
\hline \multirow[b]{2}{*}{ SMS $S_{h} *$ Post $_{t}$} & \multicolumn{2}{|c|}{ A. Visited Clinic } \\
\hline & $\begin{array}{l}0.167^{*} \\
(0.094)\end{array}$ & $\begin{array}{c}0.293^{* * *} \\
(0.109)\end{array}$ \\
\hline \multirow[b]{2}{*}{$S M S_{h} *$ Post $_{t}$} & \multicolumn{2}{|c|}{ B. Visited Clinic Because of Illness } \\
\hline & $\begin{array}{c}0.063 \\
(0.047)\end{array}$ & $\begin{array}{c}0.195^{* * *} \\
(0.065)\end{array}$ \\
\hline \multirow[b]{2}{*}{$S M S_{h} *$ Post $_{t}$} & \multicolumn{2}{|c|}{ C. Visited Clinic for Vaccine } \\
\hline & $\begin{array}{c}0.104 \\
(0.095)\end{array}$ & $\begin{array}{c}0.097 \\
(0.083)\end{array}$ \\
\hline \multirow[b]{2}{*}{$S M S_{h} *$ Post $_{t}$} & \multicolumn{2}{|c|}{ D. Received Medicine for Illness at the Clinic } \\
\hline & $\begin{array}{c}0.063 \\
(0.047) \\
109\end{array}$ & $\begin{array}{c}0.122^{* *} \\
(0.056) \\
126\end{array}$ \\
\hline & \multicolumn{2}{|c|}{ E. Received Preventive Medicine at the Clinic } \\
\hline$S M S_{h}$ & $\begin{array}{l}0.250^{* *} \\
(0.096)\end{array}$ & $\begin{array}{l}0.270^{* *} \\
(0.131)\end{array}$ \\
\hline$N$ & 96 & 68 \\
\hline \multirow[b]{2}{*}{$S M S_{h} *$ Post $_{t}$} & \multicolumn{2}{|c|}{ F. Ill in Last 30 Days } \\
\hline & $\begin{array}{l}-0.187 \\
(0.156)\end{array}$ & $\begin{array}{l}-0.210 \\
(0.192)\end{array}$ \\
\hline \multirow[b]{2}{*}{$S M S_{h} *$ Post $_{t}$} & \multicolumn{2}{|c|}{ G. Days Ill in Last 30 Days } \\
\hline & $\begin{array}{l}-3.187 \\
(1.950)\end{array}$ & $\begin{array}{c}-2.910^{* *} \\
(1.376)\end{array}$ \\
\hline \multirow[b]{2}{*}{$S M S_{h} *$ Post $_{t}$} & H. Incapacitated & ast 7 Days in Last 30 \\
\hline & $\begin{array}{l}-0.063 \\
(0.095)\end{array}$ & $\begin{array}{c}-0.209^{* *} \\
(0.085)\end{array}$ \\
\hline$N$ & 192 & 136 \\
\hline
\end{tabular}

Note: ${ }^{* * *} \mathrm{p}<0.01,{ }^{* *} \mathrm{p}<0.05,{ }^{*} \mathrm{p}<0.1$. The dependent variables in Panels $\mathrm{A}$ to $\mathrm{F}$, and Panel $\mathrm{H}$, are indicators equal to one if the statement in the panel heading is true, and zero otherwise. The dependent variable in Panel $\mathrm{G}$ is equal to the number of days, out of the last 30, the individual was ill. The estimates shown are for the coefficient $(\beta)$ on the interaction between the indicator variable for receiving SMS messages $\left(S M S_{h}\right)$ and the post-SMS indicator $\left(\right.$ Post $_{t}$ ), from equation (2); estimates in Panels E are for the coefficient on the treatment indicator and only include post-SMS observations. The vector of control variables $\left(X_{i h t}\right)$ in each equation includes a quadratic for age, the natural log of household income, and a set of village specific fixed effects. Each estimate is from a separate regression and is clustered at the household level. 


\section{Online Appendix}

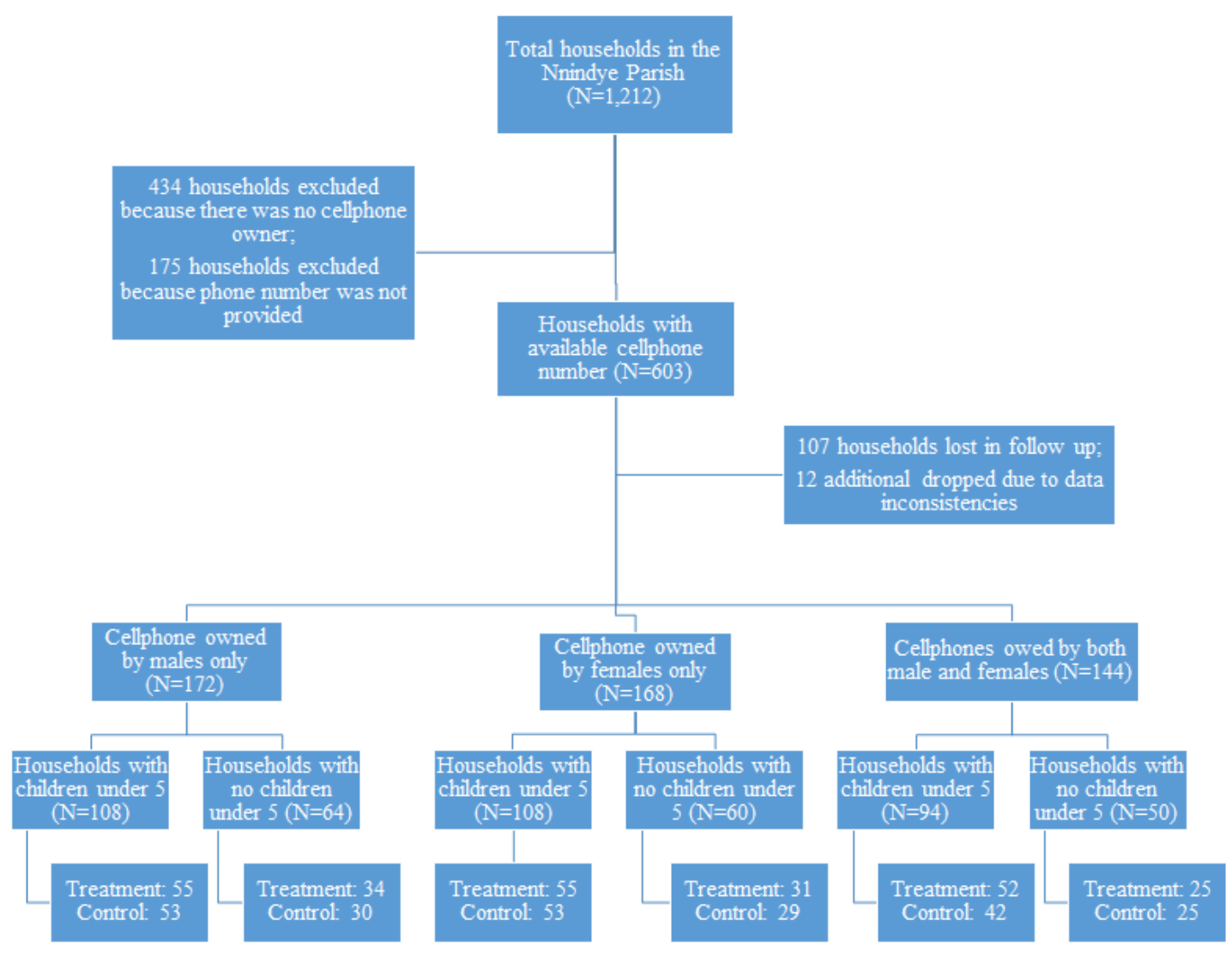

Figure A1: Experiment Profile 
Table A1: Schedule of Project and Clinic Events

\begin{tabular}{|c|c|c|c|c|c|c|c|c|c|}
\hline $\begin{array}{l}\text { Project } \\
\text { Day }\end{array}$ & Doctor & $\begin{array}{l}\text { Clinical } \\
\text { Officer }\end{array}$ & Vaccine & SMS & $\begin{array}{c}\text { Project } \\
\text { Day }\end{array}$ & Doctor & $\begin{array}{l}\text { Clinical } \\
\text { Officer }\end{array}$ & Vaccine & SMS \\
\hline 1 & & & & & 43 & & $\mathrm{X}$ & & \\
\hline 2 & & & $\mathrm{X}$ & & 44 & & $\mathrm{X}$ & & \\
\hline 3 & & & & & 45 & & $\mathrm{X}$ & $\mathrm{X}$ & $\mathrm{X}$ \\
\hline 4 & & & & & 46 & & & & \\
\hline 5 & & & & & 47 & & & & \\
\hline 6 & & & & & 48 & & & & \\
\hline 7 & & & & & 49 & & $\mathrm{X}$ & & \\
\hline 8 & $\mathrm{X}$ & & & & 50 & $\mathrm{X}$ & $\mathrm{X}$ & & $\mathrm{X}$ \\
\hline 9 & & & & & 51 & & $\mathrm{X}$ & $\mathrm{X}$ & \\
\hline 10 & & & X & & 52 & X & & & \\
\hline 11 & & & & & 53 & & & & \\
\hline 12 & & & & & 54 & & & & \\
\hline 13 & & & & & 55 & & & & \\
\hline 14 & & $\mathrm{X}$ & & & 56 & $\mathrm{X}$ & & & $\mathrm{X}$ \\
\hline 15 & & & & & 57 & & & $\mathrm{X}$ & \\
\hline 16 & & & $\mathrm{X}$ & & 58 & $\mathrm{X}$ & & & \\
\hline 17 & & & & & 59 & & & & \\
\hline 18 & & & & & 60 & & & & \\
\hline 19 & & $\mathrm{X}$ & & & 61 & & $\mathrm{X}$ & & \\
\hline 20 & & $\mathrm{X}$ & & & 62 & $\mathrm{X}$ & $\mathrm{X}$ & & \\
\hline 21 & & & $\mathrm{X}$ & $\mathrm{X}$ & 63 & & & $\mathrm{X}$ & \\
\hline 22 & & & & & 64 & $\mathrm{X}$ & & & \\
\hline 23 & & & & & 65 & & & & \\
\hline 24 & & X & & & 66 & & $\mathrm{X}$ & & \\
\hline 25 & & & & & 67 & $\mathrm{X}$ & $\mathrm{X}$ & & $\mathrm{X}$ \\
\hline 26 & & & $\mathrm{X}$ & $\mathrm{X}$ & 68 & & & $\mathrm{X}$ & \\
\hline 27 & & & & & 69 & $\mathrm{X}$ & & & \\
\hline 28 & & & & & 70 & & & & \\
\hline 29 & & $\mathrm{X}$ & & & 71 & & $\mathrm{X}$ & & \\
\hline 30 & & $\mathrm{X}$ & & $\mathrm{X}$ & 72 & & $\mathrm{X}$ & & \\
\hline 31 & & $\mathrm{X}$ & $\mathrm{X}$ & & 73 & $\mathrm{X}$ & $\mathrm{X}$ & & \\
\hline 32 & & & & & 74 & & & $\mathrm{X}$ & \\
\hline 33 & & $\mathrm{X}$ & & $\mathrm{X}$ & 75 & $\mathrm{X}$ & & & \\
\hline 34 & & & $\mathrm{X}$ & & 76 & & & & \\
\hline 35 & & & & & 77 & & $\mathrm{X}$ & & \\
\hline 36 & & & & & 78 & & $\mathrm{X}$ & & \\
\hline 37 & & & & & 79 & $\mathrm{X}$ & $\mathrm{X}$ & & $\mathrm{X}$ \\
\hline 38 & & & & & 80 & & $\mathrm{X}$ & $\mathrm{X}$ & \\
\hline 39 & & & $\mathrm{X}$ & $\mathrm{X}$ & 81 & $\mathrm{X}$ & & & \\
\hline 40 & & & $\mathrm{X}$ & & 82 & & & & \\
\hline 41 & & & & & 83 & & $\mathrm{X}$ & & \\
\hline 42 & & & & & 84 & $\mathrm{X}$ & & & $\mathrm{X}$ \\
\hline
\end{tabular}


Table A2: Effect of SMS Program: Children 0 to 6 Years Old - No Controls

\begin{tabular}{cccc}
\multicolumn{2}{c}{ Sex Relative to } & Both Man and & \\
cell phone Owner & & Woman Own \\
Same & Different & cell phone & $\begin{array}{c}\text { Difference } \\
(1)-(2)\end{array}$ \\
\hline
\end{tabular}

(1) $(3) \quad \frac{(1)}{(2)}$

\begin{tabular}{|c|c|c|c|c|}
\hline \multirow[b]{2}{*}{$S M S_{h} *$ Post $_{t}$} & \multicolumn{4}{|c|}{ A. Visited Clinic } \\
\hline & $\begin{array}{c}0.210^{* * *} \\
(0.067)\end{array}$ & $\begin{array}{l}-0.030 \\
(0.078)\end{array}$ & $\begin{array}{c}0.095 \\
(0.064)\end{array}$ & $\begin{array}{c}0.240^{* * *} \\
(0.092)\end{array}$ \\
\hline & \multicolumn{4}{|c|}{ B. Visited Clinic Because Illness } \\
\hline \multirow[t]{2}{*}{$S M S_{h} *$ Post $_{t}$} & $\begin{array}{c}0.126^{* * *} \\
(0.038)\end{array}$ & $\begin{array}{l}-0.013 \\
(0.045)\end{array}$ & $\begin{array}{c}0.026 \\
(0.037)\end{array}$ & $\begin{array}{c}0.139 * * \\
(0.058)\end{array}$ \\
\hline & \multicolumn{4}{|c|}{ C. Visited Clinic for Vaccine } \\
\hline \multirow[t]{2}{*}{$S M S_{h} *$ Post $_{t}$} & $\begin{array}{c}0.091 \\
(0.062)\end{array}$ & $\begin{array}{l}-0.040 \\
(0.071)\end{array}$ & $\begin{array}{c}0.069 \\
(0.059)\end{array}$ & $\begin{array}{c}0.132 \\
(0.082)\end{array}$ \\
\hline & \multicolumn{4}{|c|}{ D. Received Medicine for Illness at the Clinic } \\
\hline \multirow[t]{2}{*}{$S M S_{h} *$ Post $_{t}$} & $\begin{array}{c}0.092^{* * *} \\
(0.035) \\
328\end{array}$ & $\begin{array}{c}-0.033 \\
(0.032) \\
368\end{array}$ & $\begin{array}{c}0.026 \\
(0.038) \\
336\end{array}$ & $\begin{array}{c}0.125^{* * *} \\
(0.047) \\
696\end{array}$ \\
\hline & \multicolumn{4}{|c|}{ E. Received Preventive Medicine at the Clinic } \\
\hline $\begin{array}{r}S M S_{h} \\
N\end{array}$ & $\begin{array}{c}0.154^{* *} \\
(0.062) \\
164\end{array}$ & $\begin{array}{c}-0.052 \\
(0.065) \\
184\end{array}$ & $\begin{array}{c}0.081 \\
(0.058) \\
168\end{array}$ & $\begin{array}{c}0.205^{* *} \\
(0.079) \\
348\end{array}$ \\
\hline & \multicolumn{4}{|c|}{ F. Ill in Last 30 Days } \\
\hline \multirow[t]{2}{*}{$S M S_{h} *$ Post $_{t}$} & $\begin{array}{c}-0.187 \\
(0.115)\end{array}$ & $\begin{array}{c}-0.063 \\
(0.101)\end{array}$ & $\begin{array}{c}0.024 \\
(0.129)\end{array}$ & $\begin{array}{l}-0.125 \\
(0.136)\end{array}$ \\
\hline & & G. Da & Last 30 & \\
\hline \multirow[t]{2}{*}{$S M S_{h} *$ Post $_{t}$} & $\begin{array}{c}-2.947^{* *} \\
(1.236)\end{array}$ & $\begin{array}{c}0.479 \\
(1.182)\end{array}$ & $\begin{array}{c}1.547 \\
(1.394)\end{array}$ & $\begin{array}{c}-3.426^{* *} \\
(1.550)\end{array}$ \\
\hline & \multicolumn{4}{|c|}{ H. Incapacitated Due to Illness at Least 7 Days in Last 30} \\
\hline$S M S_{h} *$ Post $_{t}$ & $\begin{array}{l}-0.123^{*} \\
(0.064)\end{array}$ & $\begin{array}{c}0.043 \\
(0.062)\end{array}$ & $\begin{array}{c}0.032 \\
(0.084)\end{array}$ & $\begin{array}{c}-0.166^{* *} \\
(0.082)\end{array}$ \\
\hline$N$ & 328 & 368 & 336 & 696 \\
\hline
\end{tabular}

Note: ${ }^{* * *} \mathrm{p}<0.01,{ }^{* *} \mathrm{p}<0.05,{ }^{*} \mathrm{p}<0.1$. The dependent variables in Panels $\mathrm{A}$ to $\mathrm{F}$, and Panel $\mathrm{H}$, are indicators equal to one if the statement in the panel heading is true, and zero otherwise. The dependent variable in Panel $G$ is equal to the number of days, out of the last 30 , the individual was ill. The estimates shown in columns (1) to (3) are for the coefficient $(\beta)$ on the interaction between the indicator variable for receiving SMS messages $\left(S M S_{h}\right)$ and the post-SMS indicator (Post $t_{t}$ ), from equation (2); estimates in Panel $\mathrm{E}$ are for the coefficient on the treatment indicator and only include post-SMS observations. Estimates in column (4) are for the coefficient on the triple interaction $\left(\beta^{\text {triple }}\right)$ in equation (5), without the vector of control variables $\left(X_{i h t}\right)$; a DiD estimate is used in Panel E. Each estimate is from a separate regression and is clustered at the household level. 
Table A3: Effect of SMS Program: Children 0 to 6 Years Old - Only Households with Both Boys and Girls

\begin{tabular}{|c|c|c|c|}
\hline & \multicolumn{2}{|c|}{$\begin{array}{l}\text { Sex Relative to } \\
\text { cell phone Owner }\end{array}$} & $\begin{array}{l}\text { Difference } \\
(1)-(2)\end{array}$ \\
\hline & (1) & $(2)$ & $(3)$ \\
\hline & \multicolumn{3}{|c|}{ A. Visit Clinic } \\
\hline$S M S_{h} *$ Post $_{t}$ & $\begin{array}{c}0.223^{* *} \\
(0.102)\end{array}$ & $\begin{array}{c}-0.086 \\
(0.108)\end{array}$ & $\begin{array}{c}0.308^{* * *} \\
(0.100)\end{array}$ \\
\hline & \multicolumn{3}{|c|}{ B. Visit Clinic Because Illness } \\
\hline$S M S_{h} *$ Post $_{t}$ & $\begin{array}{l}0.103^{*} \\
(0.061)\end{array}$ & $\begin{array}{l}-0.078 \\
(0.047)\end{array}$ & $\begin{array}{c}0.180^{* *} \\
(0.075)\end{array}$ \\
\hline \multirow{3}{*}{ SMS $S_{h} *$ Post $_{t}$} & \multicolumn{3}{|c|}{ C. Visit Clinic for Vaccine } \\
\hline & $\begin{array}{c}0.097 \\
(0.093)\end{array}$ & $\begin{array}{l}-0.061 \\
(0.104)\end{array}$ & $\begin{array}{l}0.158^{*} \\
(0.088)\end{array}$ \\
\hline & \multicolumn{3}{|c|}{ D. Receive Medicine for Illness at the Clinic } \\
\hline $\begin{array}{r}S M S_{h} * \text { Post }_{t} \\
N\end{array}$ & $\begin{array}{c}0.103^{*} \\
(0.061) \\
166\end{array}$ & $\begin{array}{c}-0.025 \\
(0.027) \\
156\end{array}$ & $\begin{array}{c}0.128^{*} \\
(0.065) \\
322\end{array}$ \\
\hline & \multicolumn{3}{|c|}{ E. Receive Preventive Medicine at the Clinic } \\
\hline $\begin{array}{r}S M S_{h} \\
N\end{array}$ & $\begin{array}{c}0.248^{* *} \\
(0.111) \\
83\end{array}$ & $\begin{array}{c}0.070 \\
(0.107) \\
78\end{array}$ & $\begin{array}{c}0.175^{*} \\
(0.093) \\
161\end{array}$ \\
\hline & \multicolumn{3}{|c|}{ F. Ill in Last 30 Days } \\
\hline$S M S_{h} *$ Post $_{t}$ & $\begin{array}{l}-0.082 \\
(0.176)\end{array}$ & $\begin{array}{l}-0.028 \\
(0.150)\end{array}$ & $\begin{array}{l}-0.055 \\
(0.174)\end{array}$ \\
\hline & \multicolumn{3}{|c|}{ G. Days Ill in Last 30 Days } \\
\hline$S M S_{h} *$ Post $_{t}$ & $\begin{array}{l}-3.062 \\
(1.995)\end{array}$ & $\begin{array}{c}0.657 \\
(1.671)\end{array}$ & $\begin{array}{c}-3.718^{*} \\
(2.040)\end{array}$ \\
\hline & \multicolumn{3}{|c|}{ H. Incapacitated Due to Illness at Least 7 Days in Last 30} \\
\hline$S M S_{h} *$ Post $_{t}$ & $\begin{array}{c}-0.191^{* *} \\
(0.090)\end{array}$ & $\begin{array}{l}-0.003 \\
(0.097)\end{array}$ & $\begin{array}{r}-0.188^{*} \\
(0.107)\end{array}$ \\
\hline$N$ & 166 & 156 & 322 \\
\hline
\end{tabular}

Note: ${ }^{* *} \mathrm{p}<0.01,{ }^{* *} \mathrm{p}<0.05,{ }^{*} \mathrm{p}<0.1$. The dependent variables in Panels $\mathrm{A}$ to $\mathrm{F}$, and Panel $\mathrm{H}$, are indicators equal to one if the statement in the panel heading is true, and zero otherwise. The dependent variable in Panel $\mathrm{G}$ is equal to the number of days, out of the last 30, the individual was ill. The estimates shown in columns (1) and $(2)$ are for the coefficient $(\beta)$ on the interaction between the indicator variable for receiving SMS messages $\left(S M S_{h}\right)$ and the post-SMS indicator $\left(\right.$ Post $\left._{t}\right)$, from equation (2); estimates in Panels $\mathrm{E}$ are for the coefficient on the treatment indicator and only include post-SMS observations. Estimates in column (3) are for the coefficient on the triple interaction $\left(\beta^{\text {triple }}\right)$ in equation (5); a DiD estimate is used in Panel E. The vector of control variables $\left(X_{i h t}\right)$ in each equation includes a quadratic for age, an indicator variable for male, the natural log of household income, and a set of village specific fixed effects. Each estimate is from a separate regression and is clustered at the household level. 